\title{
Effects of heat conditioning and dietary ascorbic acid supplementation on growth performance, carcass and meat quality characteristics in heat-stressed broilers
}

\author{
H. Değer ORAL TOPLU ${ }^{1}$, Ahmet NAZLIGÜL ${ }^{1}$, Solmaz KARAARSLAN ${ }^{1}$, Mehmet KAYA ${ }^{1}$, \\ Orçun YAGIN ${ }^{2}$
}

\author{
${ }^{1}$ Adnan Menderes University, Faculty of Veterinary Medicine, ${ }^{1}$ Department of Animal Breeding and Husbandry, ${ }^{2}$ Department of \\ Animal Nutrition and Nutritional Diseases, Aydın, Turkey.
}

Summary: This study was conducted to investigate the effects of heat conditioning and dietary ascorbic acid supplementation on growth performance, carcass and meat quality characteristics in heat-stressed broilers. A total of 320 male broilers were randomly assigned to 4 treatment groups as positive control (PC), heat stress (HS), heat conditioning (HC) and ascorbic acid supplementation (AA). Broilers in PC group were housed in thermoneutral conditions $\left(24^{\circ} \mathrm{C}\right)$ and fed with the basal diet throughout experimental period. Heat stress group was exposed to $35^{\circ} \mathrm{C}$ for $6 \mathrm{~h}$ daily between 4 and 6 weeks and fed with basal diet throughout experimental period. Heat conditioned group was exposed to $36^{\circ} \mathrm{C}$ at $5 \mathrm{~d}$ of age for $24 \mathrm{~h}$, fed on the basal diet throughout experimental period and was exposed to $35^{\circ} \mathrm{C}$ for $6 \mathrm{~h}$ daily between 4 and 6 weeks. Ascorbic acid supplemented group was fed a diet supplemented with 500 $\mathrm{mg} / \mathrm{kg} \mathrm{L}$-ascorbic acid and was exposed to $35^{\circ} \mathrm{C}$ for $6 \mathrm{~h}$ daily between 4 and 6 weeks. Heat stress significantly decreased final body weight, weight gain $(\mathrm{P}<0.001)$, feed consumption, carcass yields $(\mathrm{P}<0.01)$, but increased feed conversion ratio and mortality rate $(\mathrm{P}<0.05)$. Heat stress decreased redness $(\mathrm{P}<0.001)$ and ultimate $\mathrm{pH}$ value $(\mathrm{P}<0.05)$, whereas increased lightness and cooking loss $(\mathrm{P}<0.001)$ of broiler breast meat. Heat conditioning and AA supplementation increased final body weight, weight gain, carcass yield and also improved quality characteristics of breast meat of broilers under heat stress. These results suggest that HC and dietary AA supplementation may alleviate the negative effects of heat stress on broiler performance and meat quality.

Key words: Ascorbic acid, broiler, heat conditioning, heat stress, meat quality, performance.

\section{Sıcak stresi altındaki broylerlerde erken dönem sıcağa alıştırma ve rasyona askorbik asit ilavesinin büyüme performansı karkas ve et kalite özellikleri üzerine etkileri}

Özet: Bu araştırma, sıcak stresi altındaki broylerlerde erken dönem sıcağa alıştırma ve rasyona askorbik asit ilavesinin büyüme performansı, karkas ve et kalite özellikleri üzerine etkilerini araştırmak için yapılmıştır. Toplam 320 adet erkek broyler pozitif kontrol (PC), sıcak stresi (HS), erken dönem sıcağa alıştırma (HC) ve askorbik asit ilave edilen rasyonla besleme (AA) olmak üzere dört gruba ayrılmıştır. PC grubundaki broylerler deneme süresince termonötral koşullarda $\left(24^{\circ} \mathrm{C}\right)$ yetiştirilmiş ve bazal rasyonla beslenmiştir. $\mathrm{HC}$ grubu, 5 günlük yaşta 24 saat $36^{\circ} \mathrm{C}$ ye maruz bırakılmış, deneme süresince bazal rasyonla beslenmiş ve 4-6. haftalar arasında günde 6 saat $35^{\circ} \mathrm{C}$ sıcaklığa maruz bırakılmıştır. AA grup, $500 \mathrm{mg} / \mathrm{kg}$ L-askorbik asit ilave edilen rasyonla beslenmiş ve 4-6. haftalar arasında günde 6 saat $35^{\circ} \mathrm{C}$ sıcaklığa maruz bırakılmıştır. HS grubundaki broilerler, 4-6. haftalar arasında günde 6 saat $35^{\circ} \mathrm{C}$ sıcaklığa maruz bırakılmış ve deneme süresince bazal rasyonla beslenmiştir. Sıcak stresinin final canlı ağırlık, ağırlık kazancı $(\mathrm{P}<0.001)$, yem tüketimi, karkas randımanını $(\mathrm{P}<0.01)$ azalttı̆̆ı, buna karşın yemden yararlanma oranı ve ölüm oranını artırdığ1 $(\mathrm{P}<0.05)$ belirlenmiştir. Sıcak stresi, broiler göğüs etinin kırmızılık renk indeksi $(\mathrm{P}<0.001)$ ve kesimden 24 saat sonra ölçülen $\mathrm{pH}$ değerini $(\mathrm{P}<0.05)$ azaltırken, parlaklık renk indeksi ve pişirme kaybını arttırmıştır $(\mathrm{P}<0.001)$. Erken dönem sıcağa alıştırma ve rasyona askorbik asit ilavesinin, sıcak stresi altındaki broylerlerde final canlı ağırlık, ağırlık kazancı, karkas randımanında artışa ve et kalitesinde iyileşmeye neden olduğu belirlenmiş̧ir. Bu bulgular, erken dönem sıcağa alıştırma ve rasyona askorbik asit ilavesinin, sıcak stresinin broyler performansı ve et kalitesi üzerindeki negatif etkilerini önleyebileceğini göstermektedir.

Anahtar sözcükler: Askorbik asit, broyler, et kalitesi, sıcağa alıştırma, sıcak stresi, performans.

\section{Introduction}

High ambient temperature is known as one of the major problems in broiler production especially in tropical and subtropical areas (10). Heat stress adversely affects feed intake, body weight, carcass characteristics and other traits associated with successful production and is the major cause of mortality in broilers reared in tropical environments (21). High environmental temperature affects meat quality by altering the physiology and metabolism of muscle $(20,28)$. It has been determined 
that cyclic high temperature induces oxidation stress of pectoralis major, lower $\mathrm{pH}$, denatured muscle protein and high drip loss, $\mathrm{L}^{*}$ value (lightness) and shear force in broilers (15).

Early age heat conditioning has been proposed as a technique to reinforce resistance of broiler chickens to heat stress during the finishing period (37). Ascorbic acid can be synthesized by poultry and it is not required to be supplemented to the diet under normal conditions. However, ascorbic acid supplementation might be beneficial for the performance of broilers, when they are challenged with stressors (26). High environmental temperature, may increase the requirement of ascorbic acid, decrease the biosynthesis of this vitamin and affect the endocrine system responsible for the retention and proper metabolic functioning of this vitamin (21). Ascorbic acid is one of the most important antioxidants in biological system and the supplementation of ascorbic acid is relevant to the maintenance of redox balance in heat stressed broilers (23). Dietary ascorbic acid supplementation has been reported to have positive effects on growth performance, feed intake and feed efficiency in broilers under heat stress $(7,33)$. However, there is limited information about the effects of heat conditioning and dietary ascorbic acid supplementation on meat quality characteristics in broilers under heat stress conditions.

The objective of this study was to evaluate the effects of heat conditioning and dietary ascorbic acid supplementation on growth performance, carcass and meat quality characteristics in heat-stressed broilers.

\section{Materials and Methods}

Animals and experimental design: This study was approved by local ethic committee of Adnan Menderes University (Approval No:64583101/2013/045). A total of 320 male broilers (Ross 308) obtained from a commercial hatchery were used in this study. One-day-old broilers were wing-banded, weighed and then they were randomly assigned to 4 treatment groups as positive control (PC), heat stress (HS), heat conditioning (HC) and ascorbic acid supplementation (AA). Each group consisted of 4 replicates of 20 broilers per pen. The broilers of each group were placed in a separate room and they were housed in floor pens covered with wood shavings in windowed poultry house. The size of pen was $110 \times 150 \mathrm{~cm}$. Until the 3 weeks, all broilers were raised at comfort temperature. The brooding temperature was maintained at approximately $32^{\circ} \mathrm{C}$ for the first 3 days and then decreased $3^{\circ} \mathrm{C}$ weekly until 21 days. From $4^{\text {th }}$ weeks until the end of the experiment ( 6 weeks of age), the broilers in PC group were raised in thermo neutral conditions and fed with the basal diet. The other 3 groups were exposed to heat stress in this period. Heat stress was applied exposing the broilers to a temperature of $35^{\circ} \mathrm{C}$ for
6 hours/day from 10:00 to 16:00 h. The broilers in HS group were exposed to heat stress in the period of 4 to 6 weeks of age and fed with basal diet throughout experimental period. The broilers in $\mathrm{HC}$ group was exposed to a temperature of $36^{\circ} \mathrm{C}$ for $24 \mathrm{~h}$ at the age of 5 days; fed with basal diet throughout experimental period and was exposed to heat stress in the period from 4 to 6 weeks of age. The broilers in AA group were fed a diet supplemented with $500 \mathrm{mg}$ of L-ascorbic acid $/ \mathrm{kg}$ ration and were exposed to heat stress in the period from 4 to 6 weeks of age. Average temperature was $24^{\circ} \mathrm{C}$ and relative humidity was $56 \%$ for $\mathrm{PC}$ group. Average temperature was $35^{\circ} \mathrm{C}$ from $10: 00$ to $16: 00 \mathrm{~h}$ and was $24^{\circ} \mathrm{C}$ from $16: 00$ to $10: 00 \mathrm{~h}$, relative humidity was $64 \%$ for $\mathrm{HC}, \mathrm{AA}$ and $\mathrm{HS}$ groups. Heating of poultry house was supplied with electrical heaters. Water was provided ad libitum to all groups throughout the experimental period. Continuous lighting schedule of 24 hours was provided throughout the experimental period. Broilers were fed with a starter diet from 0 to 21 days of age (3060 kcal ME/kg, 23\% crude protein) and grower diet from 22 to 42 days of age (3200 kcal ME/kg, 21.5\% crude protein). The compositions of basal diets used in starter and grower periods of the experiment are presented in Table 1.

Table 1. Composition of basal diets and calculated nutrient content.

Tablo 1. Bazal rasyonların kompozisyonu ve hesaplanan besin madde içeriği.

\begin{tabular}{lcc}
\hline Ingredients (\%) & $\begin{array}{c}\text { Starter diet } \\
(0-21 \mathrm{~d})\end{array}$ & $\begin{array}{c}\text { Grower diet } \\
(22-42 \mathrm{~d})\end{array}$ \\
\hline Vegetable oil & 1.42 & 3.04 \\
Corn & 53.58 & 55.46 \\
Soybean meal & 27.00 & 23.00 \\
Full-fat soybean & 14.00 & 15.00 \\
Di calcium phosphate (DCP) & 1.80 & 1.30 \\
DL-methionine & 0.20 & 0.10 \\
Ground limestone & 1.30 & 1.50 \\
L-lysine hydrochloride & 0.10 & 0 \\
Salt & 0.35 & 0.35 \\
Vitamin-mineral premix ${ }^{1}$ & 0.25 & 0.25 \\
\hline Calculated chemical analyses & & \\
\hline Crude protein, \% & 23.00 & 21.50 \\
ME, kkal/kg & 3060 & 3200 \\
Calcium, \% & 0.97 & 0.90 \\
Total phosphor, \% & 0.44 & 0.35 \\
Lysine, \% & 1.33 & 1.16 \\
Methionine + cystine, \% & 0.92 & 0.78 \\
\hline
\end{tabular}

: Vitamin-mineral premix contains followings for per $2.5 \mathrm{~kg}$ diet: $12000000 \mathrm{IU}$ vitamin A, $3000000 \mathrm{IU}$ Vitamin $\mathrm{D}_{3}, 30 \mathrm{~g}$ Vitamin E, $3.75 \mathrm{~g}$ vitamin $\mathrm{K}_{3}, 3 \mathrm{~g}$ vitamin $\mathrm{B}_{1}, 6 \mathrm{~g}$ vitamin $\mathrm{B}_{2}, 5$ $\mathrm{g}$ vitamin $\mathrm{B}_{6}, 20 \mathrm{mg}$ vitamin $\mathrm{B}_{12}, 40 \mathrm{~g}$ niacin, $10 \mathrm{~g}$ Ca-Dpanthotenate, $1 \mathrm{~g}$ folic acid, $50 \mathrm{mg}$ D-biotin, $500 \mathrm{~g}$ choline chloride, $80 \mathrm{~g} \mathrm{Mn}, 60 \mathrm{~g} \mathrm{Fe}, 60 \mathrm{~g} \mathrm{Zn}, 5 \mathrm{~g} \mathrm{Cu}, 0.5 \mathrm{~g} \mathrm{Co}, 1 \mathrm{~g} \mathrm{I}$, $0.15 \mathrm{~g} \mathrm{Se}$ 
Performance parameters: Mortality was recorded daily and mortality rate was calculated for the periods from 0 to 3 weeks, from 4 to 6 weeks and from 0 to 6 weeks. All broilers were weighed individually at hatch and thereafter weekly until 6 weeks of age. Feed consumption was measured weekly. Feed conversion ratio was calculated as the ratio of feed consumption to body weight gain. Cumulative body weight gain, cumulative feed consumption and feed conversion rate per bird were calculated for the periods from 0 to 3 weeks, from 4 to 6 weeks and from 0 to 6 weeks.

Carcass and meat quality measurements: At 42 days of age, five broilers whose body weights were close to the group average were selected from each pen and they were slaughtered to determine carcass and meat quality characteristics after $12 \mathrm{~h}$ of feed withdrawal. Hot and cold carcass weights were determined. Cold carcass weights were recorded after the carcasses were stored at $+4^{\circ} \mathrm{C}$ for $24 \mathrm{~h}$. Hot and cold dressing percentages were expressed as the percentages of body weight at slaughter. Each carcass was cut into five parts as breast, thigh, wing, neck and back according to the chicken cut technique of TSE (5) and then they were weighed. Carcass parts yield were expressed as the percentage of cold carcass weight.

Breast muscles and thigh muscles were used to determine meat quality characteristics. $\mathrm{pH}$ of meat was measured $15 \mathrm{~min}$ postmortem $\left(\mathrm{pH}_{15}\right)$ and $24 \mathrm{~h}$ after slaughter using a digital $\mathrm{pH}$ meter (Testo 205). Muscle color was measured on the surface on left breast and thigh muscles $24 \mathrm{~h}$ after slaughter. Color measurement was performed using a Minolta CR 400 chroma-meter (Konica Minolta Sensing, Inc., Osaka, Japan) in the CIELAB color space using a D65 illuminant, in which $\mathrm{L}^{*}$ indicates relative lightness, $\mathrm{a}^{*}$ indicates relative redness and $\mathrm{b}^{*}$ represents relative yellowness. Three $\mathrm{pH}$ and color measurements were taken for each sample. Cooking loss was determined in meat samples placed inside polyethylene bags in a water bath. Samples were heated until an internal temperature of $75^{\circ} \mathrm{C}$ and cooled for 15 min under running tap water. They were taken from the bags, dried with filter paper and weighed. Cooking loss was expressed as the percentage of loss related to the initial weight (17).

Statistical analysis: Chi square test was performed for the statistical analysis of mortality rate (35). The growth performance, carcass and meat quality characteristics were analyzed by one-way analysis of variance using SPSS 13.0 packed program (34). Significant differences among treatment means were determined using Duncan's multiple range test (12).

\section{Results}

In the present study, no mortality was recorded in HC group at the age of 5 days and there were no significant differences among groups in terms of mortality rate in the period from 0 to 3 weeks of age $\left(\mathrm{X}^{2}\right.$ $=1.009)$. However, there were significant differences among treatment groups in terms of mortality rate in the periods from 4 to 6 weeks of age $\left(\mathrm{X}^{2}=11.21, \mathrm{P}<0.05\right)$ and from 0 to 6 weeks of age $\left(\mathrm{X}^{2}=10.00, \mathrm{P}<0.05\right)$. The highest mortality rate was recorded for HS group with $10.13 \%$, followed by $\mathrm{HC}$ group $(3.80 \%)$ and AA group $(2.50 \%)$ from 4 to 6 weeks of age. However, no mortality was observed in PC group in this period. The mortality rates in the period from 0 to 6 weeks of age were $11.25 \%, 5 \%, 2.5 \%$ and $1.25 \%$ for $\mathrm{HS}, \mathrm{HC}, \mathrm{AA}$ and PC groups, respectively.

Weekly body weight gains of broilers in PC, HS, $\mathrm{HC}$ and AA groups are presented in Figure 1. There were no significant differences among groups in terms of weekly body weight gain in the period from 0 to 3 weeks of age. However, significant variations among groups were observed after $4^{\text {th }}$ week. In weeks 5 and 6 , the highest weight gain was recorded for broilers in PC group and the difference between PC and HS groups in terms of this trait was statistically significant $(\mathrm{P}<0.05)$. Body weight gain of broilers in $\mathrm{HC}$ and AA groups in these weeks was higher than those in HS group, but the differences were not statistically significant. Weekly feed consumption and feed conversion ratio of broilers in PC, $\mathrm{HS}, \mathrm{HC}$ and AA groups are shown in Figure 2 and Figure 3. No significant differences were observed among groups in terms of weekly feed conversion ratio throughout experimental period. Weekly feed consumption was not statistically significant among groups in the period from 0 to 3 weeks of age. In weeks 4, 5 and 6 , feed consumption was significantly higher for broilers in PC group, compared with HS group $(\mathrm{P}<0.05)$. HC group had significantly higher feed consumption than HS group in weeks $4^{\text {th }}$ and $5^{\text {th }}$. However, the difference among AA and HS groups was not statistically significant.

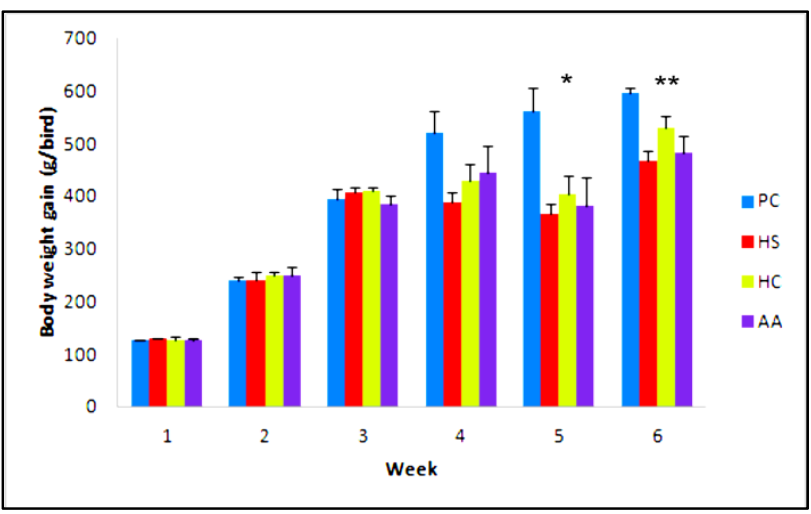

Figure 1. Weekly body weight gain of broilers in positive control, heat stress, heat conditioned and ascorbic acid supplemented groups $(\mathrm{g} / \mathrm{bird})$.

Şekil 1. Pozitif kontrol, sıcak stres, erken dönem sıcağa alıştırilan ve askorbic asit ilave edilen yemle beslenen gruplardaki broylerlerin haftalık canlı ağırlık artışları (g/broyler).

PC: Positive control, HS: Heat stress, HC: Heat conditioning

AA: Ascorbic acid supplementation.

$*: \mathrm{P}<0.05, \quad * *: \mathrm{P}<0.01$ 


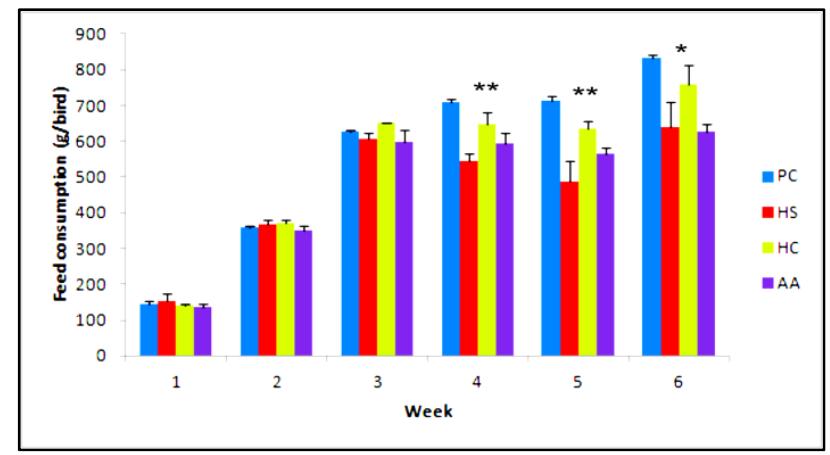

Figure 2. Weekly feed consumption of broilers in positive control, heat stress, heat conditioned and ascorbic acid supplemented groups (g/bird).

Şekil 2. Pozitif kontrol, sıcak stres, erken dönem sıcağa alıştırılan ve askorbic asit ilave edilen yemle beslenen gruplardaki broylerlerin haftalık yem tüketimi (g/broyler).

PC: Positive control, HS: Heat stress, HC: Heat conditioning

AA: Ascorbic acid supplementation.

$*: \mathrm{P}<0.05, \quad$ **: $\mathrm{P}<0.01$

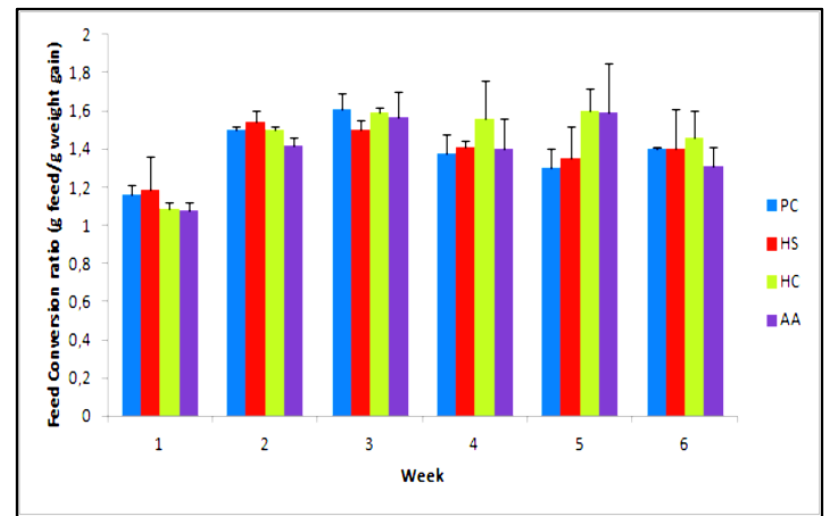

Figure 3. Weekly feed conversion ratio of broilers in positive control, heat stress, heat conditioned and ascorbic acid supplemented groups ( $\mathrm{g}$ feed/g weight gain).

Şekil 3. Pozitif kontrol, sıcak stres, erken dönem sıcağa alıştırılan ve askorbic asit ilave edilen yemle beslenen gruplardaki broylerlerin haftalı yemden yararlanma oranı ( $\mathrm{g}$ yem/g ağırlık kazancı).

PC: Positive control, HS: Heat stress, HC: Heat conditioning, AA: Ascorbic acid supplementation.

Table 2. Initial and final body weight, cumulative body weight gain, feed consumption and feed conversion ratio of broilers.

Tablo 2. Broylerlerin başlangıç ve besi sonu canlı ağırlık, kümülatif ağırlık kazancı, yem tüketimi, yemden yararlanma oranı değerleri.

\begin{tabular}{|c|c|c|c|c|c|c|c|c|c|}
\hline \multirow{3}{*}{ Traits $^{1}$} & \multicolumn{8}{|c|}{ Treatments $^{2}$} & \multirow{3}{*}{ Significance } \\
\hline & \multicolumn{3}{|c|}{$\mathrm{PC}$} & \multirow[t]{2}{*}{ HS } & \multirow{2}{*}{\multicolumn{2}{|c|}{$\mathrm{HC}$}} & \multirow{2}{*}{\multicolumn{2}{|c|}{ AA }} & \\
\hline & $n$ & & $n$ & & & & & & \\
\hline Initial body weight (g) & 80 & $47.33 \pm 0.38$ & 80 & $47.12 \pm 0.44$ & 80 & $47.36 \pm 0.37$ & 80 & $46.10 \pm 0.40$ & ns \\
\hline Final body weight (g) & 79 & $2487.8 \pm 23.21^{\mathrm{a}}$ & 71 & $2049.4 \pm 15.90^{\mathrm{d}}$ & 76 & $2196.3 \pm 18.27^{b}$ & 78 & $2111.8 \pm 21.15^{\mathrm{c}}$ & $* * *$ \\
\hline \multicolumn{10}{|c|}{ Body weight gain (g/chick) } \\
\hline 0 to 3 weeks & 4 & $764.9 \pm 20.65$ & 4 & $782.3 \pm 15.17$ & 4 & $786.7 \pm 13.89$ & 4 & $760.3 \pm 4.85$ & ns \\
\hline 4 to 6 weeks & 4 & $1676.1 \pm 17.18^{\mathrm{a}}$ & 4 & $1220.0 \pm 26.32^{\mathrm{c}}$ & 4 & $1363.5 \pm 16.68^{b}$ & 4 & $1308.7 \pm 30.77^{b}$ & $* * *$ \\
\hline 0 to 6 weeks & 4 & $2441.0 \pm 35.53^{\mathrm{a}}$ & 4 & $2001.8 \pm 24.03^{\mathrm{c}}$ & 4 & $2149.4 \pm 22.48^{b}$ & 4 & $2067.1 \pm 33.46^{\mathrm{bc}}$ & $* * *$ \\
\hline \multicolumn{10}{|c|}{ Feed consumption (g/chick) } \\
\hline 0 to 3 weeks & 4 & $1133.2 \pm 14.18$ & 4 & $1127.0 \pm 26.06$ & 4 & $1163.7 \pm 13.72$ & 4 & $1086.2 \pm 37.59$ & ns \\
\hline 4 to 6 weeks & 4 & $3056.8 \pm 22.94^{\mathrm{a}}$ & 4 & $2693.3 \pm 90.36^{\mathrm{b}}$ & 4 & $2802.2 \pm 96.43^{b}$ & 4 & $2587.6 \pm 32.80^{\mathrm{b}}$ & $* *$ \\
\hline 0 to 6 weeks & 4 & $4190.0 \pm 25.03^{\mathrm{a}}$ & 4 & $3820.4 \pm 70.91^{b c}$ & 4 & $3965.9 \pm 96.04^{b}$ & 4 & $3673.8 \pm 22.45^{\mathrm{c}}$ & $* * *$ \\
\hline \multicolumn{10}{|c|}{ Feed conversion ratio ( $\mathrm{g}$ feed/g gain) } \\
\hline 0 to 3 weeks & 4 & $1.49 \pm 0.04$ & 4 & $1.45 \pm 0.05$ & 4 & $1.48 \pm 0.02$ & 4 & $1.43 \pm 0.05$ & $\mathrm{~ns}$ \\
\hline 4 to 6 weeks & 4 & $1.82 \pm 0.01^{\mathrm{b}}$ & 4 & $2.21 \pm 0.12^{\mathrm{a}}$ & 4 & $2.06 \pm 0.07^{\mathrm{ab}}$ & 4 & $1.98 \pm 0.04^{\mathrm{ab}}$ & $*$ \\
\hline 0 to 6 weeks & 4 & $1.72 \pm 0.02^{\mathrm{c}}$ & 4 & $1.91 \pm 0.05^{\mathrm{a}}$ & 4 & $1.85 \pm 0.04^{\mathrm{ab}}$ & 4 & $1.78 \pm 0.03^{\mathrm{bc}}$ & $*$ \\
\hline
\end{tabular}

${ }^{1}$ : Initial and final body weights measured as individually, Body weight gain, feed consumption and feed conversion ratio was calculated on a pen basis.

$\mathrm{n}$ represents the number of broiler in each group for initial and final body weights, whereas the number of pen in each group for body weight gain, feed consumption and feed conversion ratio.

a, b, c: Mean values within a row with no common superscript differ significantly $(\mathrm{P}<0.05)$.

ns: non significant $\quad *: \mathrm{P}<0.05 \quad * *: \mathrm{P}<0.01 \quad * *: \mathrm{P}<0.001$
2

${ }^{2} \mathrm{PC}$ : Positive control (This group was housed in thermoneutral conditions $\left(24^{\circ} \mathrm{C}\right)$ and fed with the basal diet). HS: Heat stress (This group was exposed to $35^{\circ} \mathrm{C}$ for $6 \mathrm{~h}$ daily from 4 to $6 \mathrm{wk}$ and fed with basal diet) HC: Heat conditioning (This group was exposed to $36^{\circ} \mathrm{C}$ at $5 \mathrm{~d}$ of age for $24 \mathrm{~h}$, fed with basal diet and was exposed to $35^{\circ} \mathrm{C}$ for $6 \mathrm{~h}$ daily from 4 to $6 \mathrm{wk}$ ). AA: Ascorbic acid supplementation (This group was fed a diet supplemented with $500 \mathrm{mg} / \mathrm{kg} \mathrm{L}$-ascorbic acid and was exposed to $35^{\circ} \mathrm{C}$ for $6 \mathrm{~h}$ daily from 4 to $6 \mathrm{wk})$. 
Initial and final body weight, cumulative body weight gain, feed consumption and feed conversion ratio of broilers in the periods are summarized in Table 2. There were no significant differences among groups in terms of initial body weight, cumulative body weight gain, feed consumption and feed conversion ratio in the periods from 0 to 3 weeks of age. Heat stress significantly decreased final body weight, body weight gain $(\mathrm{P}<0.001)$, cumulative feed consumption $(\mathrm{P}<0.01)$, but significantly increased feed conversion ratio $(\mathrm{P}<0.05)$ in the periods from 4 to 6 weeks of age and from 0 to 6 weeks of age. The broilers in HS group had significantly lower final body weight and body weight gain from 4 to 6 weeks of age than those in HC and AA groups and had significantly lower body weight gain from 0 to 6 weeks of age than $\mathrm{HC}$ group $(\mathrm{P}<0.001)$. There were no significant differences between HS and HC groups and between HS and AA groups in terms of cumulative feed consumption in the periods from 3 to 6 weeks of age and from 0 to 6 weeks of age.

Hot and cold carcass yields, the percentages of carcass parts and internal organs are shown in Table 3. Heat stress significantly influenced the carcass characteristics and the percentages of internal organs of broilers. Hot $(\mathrm{P}<0.001)$ and cold carcass $(\mathrm{P}<0.01)$ yields, the percentages of breast $(\mathrm{P}<0.001)$ and abdominal fat $(\mathrm{P}<0.05)$ were significantly lower, whereas the percentages of neck $(\mathrm{P}<0.01)$, wings, back, liver $(\mathrm{P}<0.05)$ and gizzard $(\mathrm{P}<0.001)$ were significantly higher in HS group than those in $\mathrm{PC}$ group. $\mathrm{HC}$ and $\mathrm{AA}$ supplementation improved hot and cold carcass yields and abdominal fat yield of broilers exposed to heat stress.

Some meat quality characteristics measured on breast and thigh meat of broilers are summarized in Table 4. There were significant differences among treatment groups in terms of quality characteristics of breast and thigh meat. Initial $(\mathrm{P}<0.001)$ and ultimate $\mathrm{pH}$ values $(\mathrm{P}<0.05)$ of breast and thigh meat of broilers in HS group were lower compared with those in PC group. The $\mathrm{L}^{*}$ value of breast $(\mathrm{P}<0.001)$ and thigh meat $(\mathrm{P}<0.05)$ of broilers in HS group were significantly higher, whereas $\mathrm{a}^{*}$ value of breast $(\mathrm{P}<0.001)$ and thigh meat $(\mathrm{P}<0.05)$ were lower, compared with $\mathrm{PC}$ group. Cooking loss of breast $(\mathrm{P}<0.001)$ and thigh meat $(\mathrm{P}<0.01)$ of broilers in heat stress group were higher than those in PC group.

\section{Discussion and Conclusion}

Heat stress significantly increased the mortality rate of broilers in the period from 4 to 6 weeks of age. Heat conditioning and AA supplementation relieved the negative effects of heat stress on viability of broilers. It has been reported that the lower mortality of heat conditioned broilers may be due to better ability to maintain body temperatures (37). Yalcin et al. (38) also recorded the lower mortality rate for broilers exposed to $36^{\circ} \mathrm{C}$ at 5 days of age than those in control group under heat stress conditions. Decreased mortality with dietary AA supplementation may be due to the fact that AA

Table 3. Hot and cold carcass yields, the percentages of carcass parts and internal organs of broilers (\%).

Tablo 3. Broylerlerin sıcak ve soğuk karkas randımanı, karkas parça ve iç organ oranları (\%).

\begin{tabular}{|c|c|c|c|c|c|}
\hline \multirow[b]{2}{*}{ Traits } & \multicolumn{3}{|c|}{ Treatments $^{1}$} & \multirow[b]{2}{*}{ AA } & \multirow{2}{*}{ Significance } \\
\hline & $\mathrm{PC}$ & HS & $\mathrm{HC}$ & & \\
\hline Hot carcass yield & $76.93 \pm 0.37^{\mathrm{a}}$ & $74.28 \pm 0.35^{\mathrm{c}}$ & $76.44 \pm 0.40^{\text {ab }}$ & $75.59 \pm 0.26^{\mathbf{b}}$ & $* * *$ \\
\hline Cold carcass yield & $74.22 \pm 0.35^{\mathrm{a}}$ & $71.82 \pm 0.59^{\mathbf{b}}$ & $73.64 \pm 0.42^{\mathrm{a}}$ & $73.03 \pm 0.31^{\mathrm{ab}}$ & $* *$ \\
\hline \multicolumn{6}{|c|}{${ }^{2}$ The percentage of carcass parts } \\
\hline Breast & $35.28 \pm 0.41^{\mathrm{a}}$ & $32.05 \pm 0.61^{\mathbf{b}}$ & $33.51 \pm 0.54^{\mathrm{b}}$ & $32.35 \pm 0.59^{\mathbf{b}}$ & $* * *$ \\
\hline Thigh & $28.94 \pm 0.43$ & $29.62 \pm 0.49$ & $29.18 \pm 0.51$ & $30.02 \pm 0.40$ & ns \\
\hline Wings & $11.03 \pm 0.19^{\mathbf{b}}$ & $11.76 \pm 0.26^{\mathrm{a}}$ & $11.59 \pm 0.21^{\mathbf{a b}}$ & $11.92 \pm 0.20^{\mathrm{a}}$ & $*$ \\
\hline Back & $16.97 \pm 0.39^{\mathbf{b}}$ & $18.54 \pm 0.31^{\mathrm{a}}$ & $17.61 \pm 0.32^{\mathbf{a b}}$ & $17.42 \pm 0.49^{\mathbf{a b}}$ & $*$ \\
\hline Neck & $5.85 \pm 0.13^{\mathbf{b}}$ & $6.51 \pm 0.18^{\mathrm{a}}$ & $6.40 \pm 0.15^{\mathrm{a}}$ & $6.59 \pm 0.19^{\mathrm{a}}$ & $* *$ \\
\hline Abdominal fat & $1.91 \pm 0.13^{\mathrm{a}}$ & $1.40 \pm 0.09^{\mathbf{b}}$ & $1.71 \pm 0.14^{\mathrm{ab}}$ & $1.58 \pm 0.13^{\mathrm{ab}}$ & $*$ \\
\hline \multicolumn{6}{|c|}{${ }^{3}$ The percentage of internal organs } \\
\hline Heart & $0.47 \pm 0.01$ & $0.43 \pm 0.02$ & $0.43 \pm 0.02$ & $0.44 \pm 0.01$ & ns \\
\hline Liver & $1.78 \pm 0.05^{\mathbf{b}}$ & $1.95 \pm 0.07^{\mathrm{a}}$ & $1.72 \pm 0.07^{\mathbf{b}}$ & $1.70 \pm 0.04^{\mathbf{b}}$ & $*$ \\
\hline Gizzard & $1.26 \pm 0.05^{\mathrm{c}}$ & $1.81 \pm 0.09^{\mathrm{a}}$ & $1.40 \pm 0.07^{\mathbf{b c}}$ & $1.55 \pm 0.06^{\mathrm{b}}$ & $* * *$ \\
\hline
\end{tabular}

${ }^{1} \mathrm{PC}$ : Positive control (This group was housed in thermoneutral conditions $\left(24^{\circ} \mathrm{C}\right)$ and fed with the basal diet). HS: Heat stress (This group was exposed to $35^{\circ} \mathrm{C}$ for $6 \mathrm{~h}$ daily from 4 to $6 \mathrm{wk}$ and fed with basal diet) HC: Heat conditioning (This group was exposed to $36^{\circ} \mathrm{C}$ at $5 \mathrm{~d}$ of age for $24 \mathrm{~h}$, fed with the basal diet and was exposed to $35^{\circ} \mathrm{C}$ for $6 \mathrm{~h}$ daily from 4 to 6 wk). AA: Ascorbic acid supplementation (This group was fed a diet supplemented with $500 \mathrm{mg} / \mathrm{kg} \mathrm{L}$-ascorbic acid and was exposed to $35^{\circ} \mathrm{C}$ for $6 \mathrm{~h}$ daily from 4 to $6 \mathrm{wk}$ ).

2: The percentage of carcass parts weights to cold carcass weight

${ }^{3}$ : The percentage of internal organ weights to pre slaughter live weight

a, b, c: Mean values within a row with no common superscript differ significantly $(\mathrm{P}<0.05) . \quad \mathrm{n}=20$

ns: non significant $\quad *$ : $\mathrm{P}<0.05 \quad * *$ : $\mathrm{P}<0.01 \quad * * *$ : $\mathrm{P}<0.001$ 
Table 4. Some meat quality characteristics measured on breast and thigh meat of broilers.

Tablo 4. Broylerlerin göğüs ve but etinden ölçülen bazı et kalite özellikleri.

\begin{tabular}{|c|c|c|c|c|c|}
\hline \multirow{2}{*}{ Traits } & \multicolumn{4}{|c|}{ Treatments $^{1}$} & \multirow[b]{2}{*}{ Significance } \\
\hline & $\mathrm{PC}$ & HS & $\mathrm{HC}$ & AA & \\
\hline \multicolumn{6}{|l|}{ Breast } \\
\hline $\mathrm{pH}_{15}$ & $6.33 \pm 0.04^{\mathrm{a}}$ & $6.05 \pm 0.03^{\mathrm{c}}$ & $6.22 \pm 0.05^{\mathrm{ab}}$ & $6.16 \pm 0.04^{b c}$ & $* * *$ \\
\hline $\mathrm{pH}_{24}$ & $5.94 \pm 0.06^{\mathrm{a}}$ & $5.68 \pm 0.06^{\mathbf{b}}$ & $5.91 \pm 0.07^{\mathrm{a}}$ & $5.73 \pm 0.09^{\mathbf{a b}}$ & $*$ \\
\hline $\mathrm{L}^{*}$ & $50.64 \pm 0.45^{\mathbf{c}}$ & $56.79 \pm 0.71^{\mathrm{a}}$ & $52.80 \pm 0.50^{\mathbf{b}}$ & $53.58 \pm 0.42^{\mathbf{b}}$ & $* * *$ \\
\hline$a^{*}$ & $5.12 \pm 0.14^{\mathrm{a}}$ & $3.93 \pm 0.15^{\mathbf{b}}$ & $4.85 \pm 0.24^{\mathrm{a}}$ & $4.20 \pm 0.26^{\mathbf{b}}$ & $* * *$ \\
\hline$b^{*}$ & $3.81 \pm 0.11$ & $4.19 \pm 0.13$ & $3.77 \pm 0.10$ & $4.04 \pm 0.16$ & ns \\
\hline Cooking loss (\%) & $21.59 \pm 0.59^{\mathrm{c}}$ & $30.04 \pm 0.99^{\mathrm{a}}$ & $23.92 \pm 0.83^{\mathbf{b}}$ & $24.31 \pm 0.57^{\mathbf{b}}$ & $* * *$ \\
\hline \multicolumn{6}{|l|}{ Thigh } \\
\hline $\mathrm{pH}_{15}$ & $6.54 \pm 0.03^{\mathrm{a}}$ & $6.21 \pm 0.05^{\mathrm{c}}$ & $6.45 \pm 0.05^{\mathrm{ab}}$ & $6.39 \pm 0.04^{\mathbf{b}}$ & $* * *$ \\
\hline $\mathrm{pH}_{24}$ & $6.29 \pm 0.04^{\mathrm{a}}$ & $5.97 \pm 0.06^{\mathbf{c}}$ & $6.19 \pm 0.06^{\mathbf{a b}}$ & $6.12 \pm 0.05^{\mathbf{b}}$ & $* * *$ \\
\hline $\mathrm{L}^{*}$ & $48.41 \pm 1.56^{\mathbf{b}}$ & $55.33 \pm 1.22^{\mathrm{a}}$ & $50.66 \pm 1.23^{\mathbf{b}}$ & $52.04 \pm 1.67^{\mathbf{a b}}$ & $*$ \\
\hline$a^{*}$ & $12.96 \pm 0.76^{\mathrm{a}}$ & $10.13 \pm 0.64^{\mathbf{b}}$ & $11.01 \pm 0.61^{\mathbf{a b}}$ & $12.56 \pm 0.67^{\mathrm{a}}$ & $*$ \\
\hline$b^{*}$ & $5.41 \pm 0.61$ & $5.33 \pm 0.60$ & $6.00 \pm 0.38$ & $7.05 \pm 0.52$ & ns \\
\hline Cooking loss (\%) & $28.56 \pm 0.89^{\mathbf{c}}$ & $34.83 \pm 1.45^{\mathrm{a}}$ & $32.02 \pm 0.92^{\mathbf{a b}}$ & $31.60 \pm 0.61^{\mathbf{b}}$ & $* *$ \\
\hline
\end{tabular}

${ }^{1} \mathrm{PC}$ : Positive control (This group was housed in thermoneutral conditions $\left(24^{\circ} \mathrm{C}\right)$ and fed with the basal diet). HS: Heat stress (This group was exposed to $35^{\circ} \mathrm{C}$ for $6 \mathrm{~h}$ daily from 4 to $6 \mathrm{wk}$ and fed with basal diet) HC: Heat conditioning (This group was exposed to $36^{\circ} \mathrm{C}$ at $5 \mathrm{~d}$ of age for $24 \mathrm{~h}$, fed with the basal diet and was exposed to $35^{\circ} \mathrm{C}$ for $6 \mathrm{~h}$ daily from 4 to 6 wk). AA: Ascorbic acid supplementation (This group was fed a diet supplemented with $500 \mathrm{mg} / \mathrm{kg} \mathrm{L}$-ascorbic acid and was exposed to $35^{\circ} \mathrm{C}$ for $6 \mathrm{~h}$ daily from 4 to $6 \mathrm{wk}$ ).

$\mathrm{pH}_{15}$ : Initial $\mathrm{pH}$ value measured at 15 min post mortem, $\mathrm{pH}_{24}$ : $\mathrm{pH}$ value measured at $24 \mathrm{~h}$ post mortem

a, b, c: Mean values within a row with no common superscript differ significantly $(\mathrm{P}<0.05) . \quad \mathrm{n}=20$

ns: non significant *: $\mathrm{P}<0.05 \quad * *$ : $\mathrm{P}<0.01 \quad * * *$ : $\mathrm{P}<0.001$

ameliorates stress inducing suppression of hormonal and cell mediated immunity and improves the response of chickens to cell-mediated immunity (16).

It has been well documented that heat stress causes to decrease in growth performance and feed consumption and to increase in feed conversion ratio of broilers $(1,3$, $24,31)$. In the current study, it was also determined that heat stress resulted in a decrease in final body weight and body weight gain of broilers in the periods from 4 to 6 weeks and from 0 to 6 weeks of age. This result may be explained by decreasing in feed consumption of broilers exposed to high ambient temperature for reducing metabolic heat production and maintaining homeothermy $(2,32)$. Indeed, the broilers in HS group consumed 11.89 $\%$ less feed than those in PC group in the period from 4 to 6 weeks of age. However, feed conversion ratio was higher in HS group than $\mathrm{PC}$ group in this period $(\mathrm{P}<0.05)$. Both $\mathrm{HC}$ and AA supplementation positively affected the growth performance of broilers exposed to heat stress. Heat conditioned group had significantly higher body weight gain during the periods from 4 to 6 weeks and from 0 to 6 weeks and higher final body weight at 42 days of age, compared with HS group $(\mathrm{P}<0.001)$. This finding supports the knowledge that early heat conditioning induces the heat tolerance of broiler chickens at later growth stage prior to marketing $(23,37)$. Similar results were obtained by El-Moniary et al. (13) and Yalçin et al. (39). Unlike our study, Liew et al. (22) reported that heat conditioning had no significant effect on growth performance of broilers subjected to heat stress. This difference between the studies could be attributed to the difference in heat conditioning protocol applied in the studies. In comparison with HS group, 500 $\mathrm{mg} / \mathrm{kg}$ AA supplemented diet fed group had significantly higher final body weight and body weight gain in the period from 4 to 6 weeks of age $(\mathrm{P}<0.001)$. These findings indicate that $\mathrm{AA}$ supplementation alleviated the negative effect of heat stress on growth performance of broilers. This situation could be related to suppressive effects of AA on plasma corticosterone and adrenocorticotropic hormone $(25,33)$. With regard to the effects of dietary AA supplementation on body weight gain and final body weight of broilers under heat stress, the results obtained in this study are in agreement with previous literature reports $(6,7,19,23)$. There were no significant differences among $\mathrm{HS}, \mathrm{HC}$ and AA groups in terms of cumulative feed consumption in the period from 4 to 6 weeks of age. Onu (29) also reported that $450 \mathrm{mg}$ AA supplementation $/ \mathrm{kg}$ ration did not affect feed consumption of broilers during the dry season. However, Sahin et al. (33) reported that $250 \mathrm{mg}$ AA supplementation/ $\mathrm{kg}$ ration increased feed consumption of broilers reared under high temperature $\left(32^{\circ} \mathrm{C}\right)$. Attia et al. (7) also determined that $250 \mathrm{mg}$ AA supplementation $/ \mathrm{kg}$ ration increased feed consumption of broilers exposed to $38^{\circ} \mathrm{C}$ for $4 \mathrm{~h}$ three days weekly. The differences between the 
studies in terms of feed consumption could be due to the differences in the conditions of the experiments and AA levels used in the studies. Ascorbic acid supplemented group had better feed conversion ratio, compared with HS group. This result is consistent with previous findings $(7,29,33)$.

Broilers in HS group had significantly lower hot $(\mathrm{P}<0.001)$ and cold carcass $(\mathrm{P}<0.01)$ yields than those in $\mathrm{PC}$ group. This is not surprising, since the broilers in HS group had significantly lower final body weight than those in PC group. Heat stress significantly decreased breast yield $(\mathrm{P}<0.001)$ and abdominal fat yield $(\mathrm{P}<0.05)$ and indirectly caused to increase in wings, back $(\mathrm{P}<0.05)$ and neck yields $(\mathrm{P}<0.01)$. Similar to the current study, Akşit et al. (3) reported that heat stress caused to decrease in carcass and breast yields. In the present study, the percentage of heart was not influenced by heat stress; however, the higher percentages of liver and gizzard were obtained in HS group, compared with PC group. This result may be explained as an indirect effect of decreased carcass yield in broilers exposed to heat stress. Heat conditioning and AA supplementation improved hot and cold carcass yields and abdominal fat yield of broilers exposed to heat stress. Similarly, Sahin et al. (33) and Attia et al. (7) found that $250 \mathrm{mg} \mathrm{AA}$ supplementation $/ \mathrm{kg}$ ration significantly increased carcass yield of broilers exposed to heat stress.

The $\mathrm{pH}$ value is one of the most important physical quality criteria of meat and it is widely used as a predictor of meat technological and sensory qualities. The $\mathrm{pH}$ value is a direct reflection of muscle acid content, and affects shear force, water holding capacity and color of meat $(9,14,36)$. It has been reported that seasonal heat stress accelerates post mortem metabolism and biochemical changes in the muscle, which produces a faster $\mathrm{pH}$ decline, lower ultimate $\mathrm{pH}$ and higher lightness in turkey meat (27). In this study, it was also observed that heat stress significantly decreased initial and ultimate $\mathrm{pH}$ values measured on breast and thigh meat $(\mathrm{P}<0.05)$. This result is in agreement with previous literature reports $(3,9,36,40)$.

Color is another important parameter that determines quality of meat, which is related to $\mathrm{pH}$, water holding capacity, shear force and chemical composition $(4,30)$. Breast and thigh muscles of the broilers in HS group had significantly higher lightness and lower redness, compared with those in $\mathrm{PC}$ group $(\mathrm{P}<0.05)$. Similar to the current study, Lu et al. (24) also reported the higher $\mathrm{L}^{*}$ value for the broilers reared at $34^{\circ} \mathrm{C}$ than those reared at $21^{\circ} \mathrm{C}$.

Heat stress significantly influenced cooking loss of breast $(\mathrm{P}<0.001)$ and thigh meat $(\mathrm{P}<0.01)$. Cooking loss of breast and thigh meats of broilers in HS group was higher than that control group. This result may be due to the lower ultimate $\mathrm{pH}$ value of breast and thigh meat of broilers in HS group than PC group. It has been reported that low ultimate $\mathrm{pH}$ induces structural changes in the muscle with an impairment of the technological processing ability. Artificially acidified turkey meat induces restructuration of the myofibrillar network, which also cause to a marked decrease in water holding capacity $(8,11)$.

The results from the present study revealed that both $\mathrm{HC}$ and dietary AA supplementation resulted in significant improvement of meat quality parameters measured on breast and thigh meat in broilers subjected to heat stress. HC increased ultimate $\mathrm{pH}$ and redness, whereas decreased lightness and cooking loss of broiler breast and thigh muscles. Ascorbic acid supplementation also increased ultimate $\mathrm{pH}$ and decreased lightness and cooking loss of broiler breast and thigh meat and increased redness of thigh meat. Imik et al. (18) also reported that $250 \mathrm{mg}$ AA supplementation $/ \mathrm{kg}$ ration caused to decrease in $\mathrm{L}^{*}$ value and increase in $\mathrm{a}^{*}$ and $\mathrm{b}^{*}$ of the breast meat in quails exposed to $34^{\circ} \mathrm{C}$ for 8 hours/day from 08:00 to 16:00 $\mathrm{h}$.

As a result of this study, heat stress had negative effect on growth performance, carcass and meat quality characteristics of broilers. Heat conditioning and dietary AA supplementation partly alleviated the negative effect of heat stress on these traits. The results from this study suggested that early $\mathrm{HC}$ and dietary AA supplementation should be taken into consideration as management technique to improve performance and meat quality in broilers under heat stress conditions.

\section{References}

1. Abu-Dieyeh ZHM (2006): Effect of chronic heat stress and long-term feed restriction on broiler performance. Inter J Poult Sci, 5, 185-190.

2. Ain Baziz H, Geraert PA, Padilha JCF, Guillaumin S (1996): Chronic heat exposure enhances fat deposition and modifies muscle and fat partition in broiler carcasses. Poult Sci, 75, 505-513.

3. Akşit M, Yalçın S, Özkan S, Metin K, Özdemir D (2006): Effects of temperature during rearing and crating on stress parameters and meat quality. Poult Sci, 85, 1867-1874.

4. Allen CD, Fletcher DL, Northcutt JK, Russell SM (1998): The relationship of broiler breast colour to meat quality and shelf-life. Poult Sci, 77, 361-366.

5. Anonymous (1989): Türk standartları tavuk gövde eti parçalama kuralları.

6. Attia YA, Hassan RA, Qota EMA (2009): Recovery from adverse effects of heat stress on slow-growing chicks in the tropics 1: Effect of ascorbic acid and different levels of betaine. Trop Anim Health Prod, 41, 807-818.

7. Attia YA, Hassan RA, Tag EI-Din AE, Abou-Shehema BM (2011): Effect of ascorbic acid or increasing metabolizable energy level with or without supplementation of some essential amino acids on productive and physiological traits of slow-growing chicks exposed to chronic heat stress. J Anim Physiol Anim Nutr (Berl), 95, 744-755. 
8. Barbut S (1997): Microstructure of white and dark turkey meat batters as affected by $p H$. Br Poult Sci, 38, 175-182.

9. Dai SF, Wang LK, Wen AY, Wang LX, Jin GM (2009): Dietary glutamine supplementation improves growth performance, meat quality and colour stability of broilers under heat stress. Br Poult Sci, 50, 333-340.

10. Deeb N, Chaner A (2002): Genotype by environment interaction with broiler genotypes differing in growth rate. 3. Growth rate and water consumption of broiler progeny from weight-selected versus non selected parents under normal and high ambient temperatures. Poult Sci, 81, 293330.

11. Duclos MJ, Berri C, Le Bihan-Duval E (2007): Muscle growth and meat quality. J Appl Poult Res, 16, 107-112.

12. Duncan DB (1955): Multiple range and multiple F tests. Biometrics, 11, 1-42.

13. El-Moniary MMA, Hemid AA, El-Wardany I, Gehad AE, Gouda A (2010): The effect of early age heat conditioning and some feeding programs for heat-stressed broiler chicks on: 1-Productive performance. World J Agri Sci, 6, 689-695.

14. El-Rammouz R, Berri C, Le Bihan-Duval E, Babilé R, Fernandez X (2004): Breed differences in the biochemical determinism of ultimate $\mathrm{pH}$ in breast muscle of broiler chickens-A key role AMP deaminase? Poult Sci, 83, 14451451.

15. Feng JH, Zhang MH, Zheng SS, Xie P, Li J.Q (2006): The effect of cyclic high temperature on mitochondrial ROS production, $\mathrm{Ca}^{2+}$-ATPase activity and breast meat quality of broilers. Chin J Anim Vet Sci, 37, 1304-1311.

16. Gross WB, Siegel HS (1983): Evaluation of heterophil/ lymphocyte ratio as a measure of stress in chicken. Avian Disease, 27, 972-979.

17. Honikel KO (1998): Reference methods for the assessment of physical characteristics of meat. Meat Sci, 49, 447-457.

18. Imik H, Atasever MA, Koc M, Atasever M, Ozturan K (2010): Effect of dietary supplementation some antioxidants on growth performance, carcass composition, and breast meat characteristics in quail reared under heat stress. Czech J Anim Sci, 55, 209-220.

19. Imik H, Ozlu H, Gumus R, Atasever MA, Urcar S, Atasever M (2012): Effects of ascorbic acid and $\alpha$-lipoic acid on performance and meat quality of broilers subjected to heat stress. Br Poult Sci, 53, 800-808.

20. Kadim IT, Al-Quamshui BHA, Mahgoub O, AlMarzooqi W, Johnson EH (2009): Effects of ascorbic acid and seasonal temperatures on meat quality characteristics of broiler chickens maintained in opensided and closed houses. Int J Poult Sci, 8, 733-739.

21. Khan RU, Naz S, Nikousefat Z, Selvaggi M, Laudadio V, Tufarelli V (2012): Effect of ascorbic acid in heatstressed poultry. Worlds Poult Sci J, 68, 477-489.

22. Liew PK, Zülkifli I, Hair-Bejo M, Omar AR, Israf DA (2003): Effects of early age feed restriction and heat conditioning on heat shock protein 70 expression, resistance to infectious bursal disease and growth in male broiler chickens subjected to heat stress. Poult Sci, 82, 1879-1885.

23. Lin H, Jiao HC, Buyse J, Decuypere E (2006): Strategies for preventing heat stress in poultry. Worlds Poult Sci J, 62, 71-85.

24. Lu Q, Wen J, Zhang H (2007): Effect of chronic heat exposure on fat deposition and meat quality in two genetic types of chicken. Poult Sci, 86, 1059-1064.
25. Mahmoud KZ, Edens FW, Havenstein GB (2004): Ascorbic acid decreases heat shock protein 70 and plasma corticosterone response in broilers (Gallus domesticus) subjected to cyclic heat stress. Comp Biochem Physiol B, 137, 35-42.

26. McKee JS, Hurrison PC (1995): Effects of supplemental ascorbic acid on the performance of broiler chickens exposed to multiple concurrent stressors. Poult Sci, 74, 1772-1785.

27. McKee SR, Sams AR (1997): The effect of seasonal heat stress on rigor development and the incidence of pale, exudative turkey meat. Poult Sci, 76, 1616-1620.

28. Northcutt JK, Foegeding EA, Edens FW (1994): Waterholding properties of thermally preconditioned chickens breast and leg meat. Poult Sci, 73, 308-316.

29. Onu PN (2009): Growth Performance, carcass characteristics and economic benefits of supplemental ascorbic acid on broiler starters exposed to heat stress. J Agric Biol Sci, 4, 19-23.

30. Qiao M, Fletcher DL, Northcutt JK, Smith DP (2002): The relationship between raw broiler breast meat color and composition. Poult Sci, 81, 422-427.

31. Quinteiro-Filho WM, Ribeiro A, Ferraz-de-Paula V, Pinheiro ML, Sakai M, Sá LRM, Ferreira AJP, Palermo-Neto J (2010): Heat stress impairs performance parameters, induces intestinal injury, and decreases macrophage activity in broiler chickens. Poult Sci, 89, 1905-1914.

32. Ryder AA, Feddes JJR, Zuidhof MJ (2004): Field study to relate heat stress index to broiler performance. J Appl Poult Res, 13, 493-499.

33. Sahin K, Sahin N, Kucuk O (2003): Effects of chromium, and ascorbic acid supplementation on growth, carcass traits, serum metabolites, and antioxidant status of broiler chickens reared at a high ambient temperature $\left(32^{\circ} \mathrm{C}\right)$. Nutr Res, 23, 225-238.

34. SPSS (2004): Statistical package for social science for windows. Version 13.0 (Chicago, IL, SPSS Inc.),

35. Steel RGD, Torrie JH (1980): Principles and Procedures of Statistics: A Biometrical Approach, $2_{\text {nd }}$ Ed., New York.

36. Wang RR, Pan XJ, Peng ZQ (2009): Effects of heat exposure on muscle oxidation and protein functionalities of pectoralis majors in broilers. Poult Sci, 88, 1078-1084.

37. Yahav S, Hurwitz S (1996): Induction of thermotolerance in male broiler chickens by temperature conditioning at an early age. Poult Sci, 75, 402-406.

38. Yalcin S, Özkan S, Türkmut L, Siegel PB (2001): Responses to heat stress in commercial and local broiler stocks. 1. Performance traits. Br Poult Sci, 42, 149-152.

39. Yalçin S, Özkan S, Çabuk M, Siegel PB (2003): Criteria for evaluating husbandry practices to alleviate heat stress in broilers. J Appl Poult Res, 12, 382-388.

40. Zhang ZY, Jia GQ, Zuo JJ, Zhang Y, Lei J, Ren L, Feng DY (2012): Effects of constant and cyclic heat stres on muscle metabolism and meat quality of broiler breast filet and thigh meat. Poult Sci, 91, 2931-2937.

Geliş tarihi: 28.10.2013 / Kabul tarihi: 10.04.2014

Adress for correspondence:
Dr. Deger Oral Toplu
Adnan Menderes University, Faculty of Veterinary Medicine,
Department of Animal Breeding and Husbandry,
Aydın-Turkey
e-mail: doral@adu.edu.tr

Adress for correspondence:

Dr. Deger Oral Toplu

Department of Animal Breeding and Husbandry,

e-mail:doral@adu.edu.tr 